\title{
Youth unemployment and employment trajectories in Spain during the Great Recession: what are the determinants?
}

\author{
Joan Miquel Verd ${ }^{1 *}$, Oriol Barranco ${ }^{1}\left(\mathbb{D}\right.$ and Mireia Bolíbar ${ }^{2}$ (D)
}

\begin{abstract}
Since the beginning of the recession period in Europe, unemployment has greatly affected the young adult population. In this context, Spain is regarded as an extreme case, due to its exceptionally high youth unemployment rates. This article seeks to identify the determinants that have led certain groups of Spanish young people to suffer labour market trajectories with higher levels of unemployment and instability during the Great Recession than others. To do this, retrospective data from the 2012 Catalan Youth Survey are used. With these data and using cluster analysis, a typology of labour market trajectories is constructed. Next, multinomial logistic regressions are used to identify what individual socio-demographic characteristics and pre-crisis employment experiences are connected to these different typological career paths. Results show that the highly differentiated career paths are associated with different social profiles and differences in the presence of unemployment. Moreover, interesting differences among the most unstable career paths appear. For the most vulnerable social profiles the employment trajectory prior to the crisis seems to point towards the existence of an entrapment in low-skilled jobs that alternate with situations of unemployment. For those with a slightly better position their employment situation after the initiation of the crisis seems to have been impacted by their brief labour market trajectory before the crisis and their resulting work experience gap.
\end{abstract}

Keywords: Spain, Unemployment, Great Recession, Youth, Labour markets, Employment trajectories

JEL Classification: J24, J64, Z13

\section{Introduction}

Spain, along with Greece, Italy and Croatia, is one of the countries in the European Union where unemployment has hit young people the hardest during the Great Recession. In its aftermath, unemployment among Spanish workers under 25 years of age reached peaks above 50\% in 2012, 2013 and 2014. Since these peaks, the youth unemployment rate has been slowly declining, although in 2017 it continued to be above 35\% (Spanish Labour Force Survey).

\footnotetext{
*Correspondence: joanmiquel.verd@uab.cat

${ }^{1}$ Centre d'Estudis Sociologics Sobre la Vida Quotidiana i el Treball (Sociological Research Centre on Everyday Life and Work-QUIT), Institut d'Estudis del Treball (Institute for Labour Studies-IET), Universitat Autonoma de Barcelona, Building B. Campus of the Universitat Autonoma of Barcelona, 08193 Cerdanyola del Vallés, Barcelona, Spain Full list of author information is available at the end of the article
}

The destruction of youth employment in Spain during the Great Recession must be explained by the sensitivity of this population group to economic downturns, which historically and all over western countries provoke a growth in unemployment above the average found for the overall population (Lefresne 2003; Verick 2011; Choudhry et al. 2012; ILO 2016). However, the existence of country-specific characteristics that produce enormous variations among the countries of the European Union must also be taken into consideration (Pastore and Giuliani 2015; Dietrich and Möller 2016). In addition, although in Spain many have come to speak of a "lost generation"-more so in the media than in the strictly academic world-referring to all young people in a generic manner, there are major differences in the rates of unemployment among young people with different social profiles. As a result, to obtain a complete picture 
of youth unemployment it is necessary to also take into account the socio-demographic characteristics of young people and their type of insertion in the labour market (Freeman and Wise 1982).

The primary objective of this article is to identify, from a sociological perspective, what determinants are associated with youth unemployment in Spain during the Great Recession, addressing both socio-demographic characteristics as well as factors connected to career paths. Moreover, the article has the objective of framing the analysis of unemployment in the kind of labour market trajectory developed by young workers. Thus, instead of considering unemployment as a single dependent variable, the article considers periods of unemployment in connection to other events in the individual's labour market trajectory, making explicit in this way that unemployment should not be understood as an event isolated from the labour market segment in which career paths develop. Accordingly, the analysis presented is designed to discern between the influence of what we call 'social factors' (socio-demographic characteristics of individuals) and 'career factors' (the length and quality of the labour market experience) on the kind of labour market trajectory undertaken during the Great Recession.

To fully develop these initial objectives the article adopts a dynamic perspective. Firstly, employment trajectories are constructed by means of a cluster analysis to permit us to identify different types of career paths with different levels of unemployment and instability associated with them. Secondly, multinomial logistic regressions are used to examine the degree of association of these different trajectories with different sub-groups of the working youth population and the features of their trajectories in the labour market during the period previous to recession. This approach makes it possible to highlight certain new determinants, beyond individual characteristics, of the hardships faced by young people during the Great Recession in Spain.

Our starting hypothesis is that during the crisis, unemployment and unstable employment have most severely affected the trajectories of young people with sociodemographic profiles that have traditionally been more vulnerable in the Spanish labour market, as well as those who already had experienced unstable and low quality employment before the crisis.

By adopting an approach based on an analysis of employment trajectories, this article improves on existing studies on the characteristics of youth unemployment in Spain. One of the relevant findings is that long-term and short-term unemployment during the Great Recession correspond to different kinds of labour market trajectory. In addition, we find that a long employment experience prior to the onset of recession is associated with having a stable career path during recession, thus having a protective effect against unemployment. However, this is the case only for those workers not employed in the most precarious labour market segment. For the most vulnerable social profiles the length of the employment trajectory prior to the crisis had no effect. Therefore, the research reported in the article shows that the determinants of youth unemployment are better understood when taking into account the existence of different layers of labour market segmentation in Spain, and not only the difference between primary and secondary segments- or stable and unstable segments.

To our knowledge, there is no published research yet evaluating the role of unemployment in the development of employment trajectories among young people during the Great Recession in Spain. Our analysis complements that of López-Andreu and Verd (2016), who use panel data $^{1}$ to analyse the segmentation of career paths among young adult workers (individuals between 20 and 40 years old) for the period between 2007 and 2011. Their analysis, which uses a multinomial logit model, identifies the importance of industrial sectors and family background in the development of trajectories for the population considered. For the period prior to the recession the few existing analyses that have addressed the question of employment trajectories (Hernanz 2003; García-Pérez and Muñoz-Bullón 2011; Verd and López-Andreu 2012) ${ }^{2}$ have revealed the important role that the combination of unemployment and temporary contracts plays in the trajectories of employees with low educational levels, trapping them in unskilled jobs from which it is difficult to escape. The novelty of our analysis is that in addition to this most precarious trajectory-which continues to exist during the Great Recession-we find that unemployment has also hit less vulnerable profiles, whose situation of unemployment cannot be explained by only their entrapment in low-skilled jobs, but also by their lack of sufficient experience in the labour market. The identification of this intermediate segment (not stable, but not completely precarious), where the associated social profiles suffered unemployment to a lesser degree than vulnerable profiles, can be considered a contribution to the

\footnotetext{
1 The panel survey used as a source of data in their article (the Inequalities Panel of the Jaume Bofill Foundation) was discontinued in 2012. Although the data we use is not panel data, it has the advantage of providing month to month information, while the latter one provided only annual information (for instance, in terms of employment, the information provided was the most frequent situation along every year considered).

${ }^{2}$ Hernanz (2003) uses the linked Spanish Labour Force Survey (19872001) for her analysis, García-Pérez and Muñoz-Bullón (2011) use the Spanish Social Security records for the period 1996-2003, and Verd and López-Andreu (2012) use the Inequalities Panel of the Jaume Bofill Foundation-already mentioned in note 1-for the period 2001-2006.
} 
Table 1 Unemployment rates among young people (16-24 years of age). Spain and Catalonia. 2006 to 2013

\begin{tabular}{lllllllll}
\hline & $\mathbf{2 0 0 6}$ & $\mathbf{2 0 0 7}$ & $\mathbf{2 0 0 8}$ & $\mathbf{2 0 0 9}$ & $\mathbf{2 0 1 0}$ & $\mathbf{2 0 1 1}$ & $\mathbf{2 0 1 2}$ & $\mathbf{2 0 1 3}$ \\
\hline Spain & 17.9 & 18.2 & 24.6 & 37.8 & 41.6 & 46.4 & 53.2 & 54.9 \\
Catalonia & 14.7 & 13.5 & 20.4 & 37.1 & 39.5 & 44.1 & 50.7 & 50.8 \\
\hline
\end{tabular}

Source: Elaborated by authors based on data from the Statistical Institute of Catalonia (IDESCAT) and the Spanish Labour Force Survey

existing literature, revealing a new feature in relation to how unemployment impacted workers in previous economic crises.

Using a dynamic perspective poses an important methodological difficulty in the Spanish case: the lack of longitudinal databases that gather adequate data on situations of unemployment and family social background as well. To overcome this problem, we use the retrospective data provided by the 2012 Catalan Youth Survey (Enquesta a la joventut de Catalunya 2012). This survey provides a long list of relevant economic and social variables to study different dimensions of the lives of a sample of 3002 respondents. This is not a panel survey, but permits us to reconstruct the employment trajectories of young people since they were 15 years of age by means of retrospective questions; in addition it provides information on their family background.

Catalonia accounted for $19.9 \%$ of Spain's GDP and $17.4 \%$ of the country's total employment in 2007. For the year 2017 these figures where 19.2\% for GDP and $17.4 \%$ for the share of Spanish employment. Catalonia is also one of the regions with the lowest unemployment and temporary employment rates in Spain. However, these differences with the Spanish labour market as a whole are mostly quantitative-in intensity and magnitude-but not qualitative-as the key dynamics and determinants affecting the level of unemployment and temporary employment are shared by all Spanish regions. In Sect. 3.1 we provide grounds for this argument. Thus, in terms of representativeness, the relative frequencies of the different labour market trajectories analysed in the article should not be extrapolated to the whole Spanish level, however, we do believe that the conclusions regarding the determinants linked to each type of trajectory can, to a great extent, be extrapolated to the whole Spain. This should not be surprising, as the regulatory and institutional framework is the same for all regions, social stratification is similar, and the impact of the recession on the evolution of youth unemployment levels has also been very similar (see Table 1).

The rest of this article is structured in the following manner. In Sect. 2 we present a brief theoretical review of the literature that has addressed the main determinants of youth unemployment generally as well as for the Spanish case. In Sect. 3 we present our data and the methods of analysis used. In Sect. 4 we present the results of our analysis and our interpretation of them. Lastly, in Sect. 5, the concluding section, we briefly summarise these findings, and reflect upon the prospects these results may imply for Spanish youth and for policy making.

\section{Unemployment in the trajectories of the working youth population in Spain: social factors and career factors}

Table 1 shows the evolution of unemployment for Catalonia and Spain from 2006 to 2013. As can be seen, although the rates are somewhat lower in Catalonia, the impact of the Great Recession in both contexts follows an identical trend, and in both cases, the increase in youth unemployment (young people from 16 to 24 years of age) is spectacular. In 2006, youth unemployment was $17.9 \%$ for Spain overall and $14.7 \%$ in Catalonia. In 2008, with the crisis having just begun, youth unemployment was $24.6 \%$ and $20.4 \%$ respectively, and in 2013, the height of youth unemployment during the Great Recession, the rates were $54.9 \%$ and $50 \%$ respectively, rates that are more than triple that found in 2006, prior to the crisis.

What factors could account for this enormous growth in unemployment among young people in Spain and Catalonia? There are many studies that have tried to explain, from a comparative perspective, the causes for the rise in youth unemployment to such levels during the economic crisis. On the one hand, some mention the widespread introduction of temporary contracts in the years prior to the crisis, as a result of reforms "at the margin" or "two-tier reforms", which mostly affected young workers (Mertens et al. 2007; O'Reilly et al. 2015). Some authors consider these reforms to have consolidated a labour market marked by differences between insiders and outsiders (Bentolila et al. 2008), with the increase in unemployment during the crisis being caused by the large gap between the costs of firing persons with permanent versus temporary contracts and the laxer regulations on the use of the latter (Bentolila et al. 2012). From this perspective, it can be deduced that the higher rates of 
unemployment suffered by young people are due to the greater concentration of temporary contracts among this group in comparison to prime-age workers. ${ }^{3}$ On the other hand, the particular harshness with which the recession has affected Spain has also been noted (O'Higgins 2012). Within this context of crisis businesses apply the principle of last-in first-out (LIFO) to reduce their workforce (Bell and Blanchflower 2011; Rocha 2012a; Dietrich and Möller 2016), which primarily affects young people. Lastly, the existence in Spain of a deficient institutional design-too rigid and sequential-in regard to schoolto-work transitions, has also been noted (Pastore 2015; Pastore and Giuliani 2015), which makes the acquisition of employment experience among young workers more difficult, making them less attractive to employers. Possibly, the real causes can be found in a combination of the factors just mentioned, some of them shared with other Mediterranean countries, that have also been hit with a strong increase in youth unemployment (Dietrich and Möller 2016; Pastore 2017).

The above mentioned comparative approaches are useful for identifying country-specific factors that influence aggregate unemployment rates for young people in Spain. However, to obtain a complete picture of the unemployment problem it is important to connect the functioning of the labour market with the individual characteristics of young people. As stressed in the introduction, some young people are more likely than others to suffer a situation of unemployment. Thus, if we want to identify the causes for the concentration of unemployment in certain social profiles among young people, it is necessary to take into consideration the possible effect of the sociodemographic characteristics of this population and the influence of the type of insertion in the labour market, as Freeman and Wise (1982) argued some years ago.

If we look at socio-demographic characteristics, analyses based on cross-sectional data have shown that the groups that have been most affected by the destruction of employment during the Great Recession are immigrants, women, those with low education level and workers under 25 years of age (Rocha 2012a, b; Alós 2012; Alós and Lope 2015). It is not by chance that these groups are also those that occupy the most low-skilled segments of the Spanish labour market, in which unstable employment is the norm (Alós 2008, 2015). On the one hand, we must take into account that firms use temporary contracts to cover those positions in which increases in productivity are not associated with the permanence of the worker (Hernanz 2003). On the other hand, the spread of

\footnotetext{
${ }^{3}$ However, the analyses of dualisation in different employment regimes in Europe carried out by Häusermann and Schwander (2012) do not place Spain among the countries with a strong insider-outsider model.
}

the norm of flexible employment has created an "imperfect dual market" (Prieto et al. 2009) that is extremely sensitive to economic cycles (Banyuls et al. 2009; Dietrich and Möller 2016; Muñoz-de-Bustillo and Esteve 2017). Thus, in a macroeconomic context such as in Spain during the recession, everything seems to indicate that firms have responded to the crisis by discontinuing or not renewing temporary contracts. Therefore, the weak position of certain social groups-in terms of the labour market segment where they are placed-could explain, in an initial and straightforward cross-sectional approach, why individuals employed at that point (mostly in temporary jobs) lost their jobs with the initiation of the crisis. ${ }^{4}$

However, a dynamic approach must be taken to obtain a better picture of the vulnerability of certain young workers in the Spanish labour market and whether they had a greater likelihood of becoming unemployed once the recession began. At the international level evidence exists that temporary employment is a stepping stone to permanent jobs for certain groups (Eichhorst et al. 2017), although this varies significantly among countries (Scherer 2004; Berton et al. 2011; Bruno et al. 2012). But temporary employment can also lead to dead end jobs, which result in becoming trapped in instability (Scherer 2004; Barbieri and Scherer 2009; Bruno et al. 2012) and, consequently, in having increased possibility of being dismissed in a context of a lack of employment. ${ }^{5}$ Thus, if we really want to identify, from a sociological perspective, the relationship between socio-demographic characteristics and the likelihood of becoming unemployed we need to take into account the employment trajectories of young people (i.e., to address their (un)employment situations from a longitudinal perspective). Once we know these trajectories, it will be possible to identify the factors that, in the context of the particular characteristics of the Spanish labour market, shape the type of career path developed by young people during the years of economic downturn in Spain.

Moreover, a dynamic approach is necessary if we take fully into account the initial theoretical formulation of the theory of labour market segmentation (Doeringer and Piore 1971; Edwards 1975). The initial theory of segmentation stresses the temporal conception of segments, as in its understanding labour market segmentation implies that employment positions in the primary

\footnotetext{
${ }^{4}$ Already in the 1980 s Osterman (1980) and Kaliski (1984, p. 131) mentioned the preference that firms with better jobs had for contracting individuals with employment experience, which excluded young people entering the labour market.

${ }^{5}$ Becoming trapped can also occur in relation to unskilled jobs. Baert et al. (2013) and Meroni and Vera-Toscano (2017) have shown that being overqualified at the beginning of a career can be a trap that increases subsequent difficulties in finding a job consistent with the individual's skills.
} 
segments are closed to those workers in a lower segment, so that the employment trajectories of workers develop entirely in one segment (Tomlinson and Walker 2012).

Finally, the dynamic view will help us to identify the role played by career path in the years prior to the recession in relation to the employment trajectory developed after its onset. The trajectory of a person can be understood as a process that permits the accumulation of experience, skills and competencies valued by employers (Ryan 2001; Debels 2008; Pastore 2015). The question is if before a shock as significant as that produced by the economic crisis in Spain, this prior trajectory has an impact on firms in their decision to lay-off certain workers, or if lay-offs are carried out independently of previous career path. Clearly, individual trajectories prior to the crisis are not independent of individuals' socio-demographic characteristics, making it necessary to also control for these factors. Examining these relations, it is possible to evaluate the degree of path dependency of the employment trajectory after the onset of the crisis.

\section{Data and methods}

\subsection{Data}

This article uses data from the Catalan Youth Survey 2012 (Enquesta a la joventut de Catalunya 2012). This survey is aimed at a representative sample of young people in Catalonia between 15 and 34 years of age. It looks at their social characteristics, with particular emphasis on their trajectories in education, training and employment as well as processes of transition to adult life. It is produced by the Catalan Youth Observatory in collaboration with the Statistical Institute of Catalonia (IDESCAT). The survey sample size is 3002 individuals and the field work was carried out between the months of April and July of 2012. It was based on two-stage sampling by clusters with prior stratification. The units in the first stage are municipalities, stratified by territory and population size. In the second stage the units are the individuals, who are stratified by sex, age group (15-19, 20-24, 25-29 and 30-34 years of age) and nationality (Spanish or foreign). The analysis for this article has been carried out on the sub-sample of young people that at the time of the beginning of the recession were or had been active in the labour market $(\mathrm{N}=1394)$.

In the analyses we have used data for individuals between 20 and 34 years of age in order to avoid the distortions caused by the high percentage of young people under 20 still in education. Although the cut-off age of 34 to define youth may seem surprising in comparison with the age definition of youth adopted in the majority of other European countries, it is optimal for the analysis of Spanish youth (un)employment because it allows us to take into account the complexity of labour market insertion processes in Spain, which are prolonged over a greater period of time (Casal et al. 2006; Quintini et al. 2007, p.8).

The survey provides relevant information for sociological analysis as it offers rich data on individuals' social and family background. It includes variables on parents' occupational category when respondents were 15 years of age, in addition to standard variables like age, sex, place of birth and educational level. Table 4 in Appendix contains the descriptive statistics for the variables used in the analyses.

The survey also includes data on employment trajectories obtained from retrospective questions in the questionnaire. Specifically, the survey identifies the economic activities that compose respondents' trajectories from when they were 15 years of age until the point of the interview, specifying the moment they entered the labour market (month and year) and their current situation. This detailed retrospective information is especially useful for the analysis of employment trajectories. It has been used in the analyses to compute variables regarding (i) the quality of the work experience young individuals accumulated prior to the start of the recession, and, more importantly, (ii) the characteristics of their labour market trajectories during the period from October 2007 to April 2012. The latter are used to build a typology of labour market trajectories, while the former, together with socio-demographic variables, are used as covariates of the trajectory.

Finally, it is important considering the degree of representativeness of the Catalan case to account for the determinants of unemployment and labour market trajectories of young individuals in Spain as a whole. In this sense, first, it must be pointed out that Spain has relevant regional disparities in unemployment and temporary employment rates, although unemployment disparities are less marked than in Germany or Italy (López-Bazo and Montellón 2013, p. 384). The acknowledgement of these regional disparities has led some authors to group the 17 Spanish regions into high and low unemployment regions (e.g. Bande and Karanassou 2014) as well as into two groups according to the presence of temporary employment (Caparrós and Navarro 2008). ${ }^{6}$ Taking into account both types of groupings, we can identify a

\footnotetext{
${ }^{6}$ Spanish regional unemployment has been clustered in different studies (e.g. López-Bazo and Montellón 2013; Sala and Trivín 2014; Bande and Karanassou 2014). The clustering proposed by Bande and Karanassou (2014) is the one that uses data from the longest period: 1980-2010. These authors group Aragon, the Balearic Islands, Catalonia, Madrid, Navarre, the Basque Country and La Rioja into low unemployment regions, while they classify the remaining 10 Spanish regions as high unemployment regions. Caparrós and Navarro (2008), with data from 2000, group the former regions together as well along with Extremadura and Castilla-La Mancha, though leaving out the Basque Country, as the regions with a lower presence of temporary employment.
} 
cluster of regions with lower unemployment and temporary employment, which would be composed of Aragon, the Balearic Islands, Catalonia, Madrid, Navarre and La Rioja. The findings regarding the relative weight of the different labour market trajectories found in the analysis can only be extrapolated to these regions. ${ }^{7}$ Despite these differences in magnitude, the dynamics of unemployment and temporary employment seem to be the same in all the regions in Spain. In this regard, Sala and Trivín (2014) show that, for the 1996-2012 period, both low and high unemployment regions increased participation and employment levels (the latter was even slightly larger in high unemployment regions) during the period previous to economic crisis, while unemployment and spatial mobility rose up in a similar vein during the recession. Caparrós and Navarro (2008) show that in all Spanish regions being a woman, young, low-educated, low-skilled or employed in agriculture or construction sectors increase the probability of having temporary contracts. These data on the dynamics and factors linked to the labour market situation of individuals in the different Spanish regions lead us to conclude that our findings regarding the determinants linked to each type of trajectory can, to a great extent, be extrapolated to all of Spain.

\subsection{Analysis}

The employment trajectories of the young people of the sample had differing lengths at the moment of the survey, depending on how long ago they first entered the labour market. However, the focus of the analysis is on their trajectories during the crisis period (from October 2007 to April 2012), in which all have the same length of 55 months. Regarding the trajectories during the crisis, we consider the different situations of activity and employment over the course of this period as percentages of the individual's trajectory during the crisis. Based on these data we have built a typology of labour market trajectories using cluster analysis. After, we have applied multinomial logistic regressions to describe the social and career factors associated with the type of labour trajectory young people have experienced during the crisis.

The goal of the cluster analysis was to identify groups with similar labour market trajectories. This was done by measuring the percentage of time (measured in months) spent in seven types of employment situations during the four years and seven months of the economic crisis taken into consideration in our analysis. The seven distinct situations considered in the analysis are unemployment, stable employment, temporary employment (includes jobs with fixed term contracts and paid internships), nonsalaried employment (includes all forms of employment outside of dependent employment, i.e. self employment with and without employees), short odd jobs (days, weeks or a few months), informal employment (without a contract, or working in a family business without pay), and inactive.

In order to identify distinct groups based on similar trajectories as defined by these variables and to create a typology from them we have used the Ward's hierarchical clustering method (Ward 1963) through use of SPSS software. This method consists of a hierarchical cluster algorithm in which the aggregation of cases seeks the minimum loss of variance in each step, based on an assessment of their similarity calculated as the sum of squares between every pair of clusters computed over all variables (Hair et al. 2009). ${ }^{8}$ The decision on the partitioning of the cluster in a solution of $\mathrm{n}$ groups, contrary to other'model-based clustering' procedures (such as Latent Profile Analysis) that draw on assumptions of data distribution, is not based on any confirmatory test. As Hair et al. (2009) explain, it is rather based on a combination of interpretive and technical-statistical criteria. In other words, it is aimed at selecting the simplest model possible that would capture the identity of each type within the social diversity the data reflect, while taking into consideration the analysis of the values of the clustering coefficients. The clustering process is shown visually in a dendrogram (see Fig. 1 in Appendix), graphically depicting in the axis of abscissas the increase in heterogeneity at every step of the process of grouping cases and groups. In our case, of all possible solutions of 2, 3, 4, 5 or more clusters, we chose the four cluster solution because it allowed grouping internally homogeneous trajectories and showed a clearly defined profile for every group. The solution of 2 clusters, in spite of being the most optimal according to the clustering coefficients, merged trajectories that were too heterogeneous into a single group,
${ }^{7}$ Another relevant difference-although not large-regarding our objectives is the sectoral distribution of employment. In 2016 in Catalonia this distribution was the following: $1.60 \%$ of employed persons working in agriculture, 18.33 working in industry, 5.79 working in building industry, and 74.29 in services. For the whole of Spain this distribution was $4.22 \%$ of employed persons working in agriculture, 13.75 working in industry, 5.85 working in building industry, and 76.17 working in services (data from the Spanish National Statistics Institute).

\footnotetext{
${ }^{8}$ In the Ward's procedure, the selection of which two clusters to combine at each step of the agglomerative process is based on which combination of clusters minimises the within-cluster sum of squares across the complete set of disjoint or separate clusters. At each step, the two combined clusters are those that minimise the increase in the total sum of squares across all variables in all clusters, therefore clusters with a small number of observations are usually merged. The Ward method is widely-used because of its tendency to generate clusters that are homogeneous and relatively equal in size (Hair et al. 2009, p. 505).
} 
thus blurring the interpretation of the results, which was clearer in the partition into 4 clusters. ${ }^{9}$

After, we ran two multinomial logistic regressions. The first contrasts the characteristics of young people with different types of trajectories and the factors that contributed to them, such as social and family origin. Specifically, the variables used in the first regression were sex, age, place of birth (Spain or elsewhere), educational level and parents' occupational status. This variable was introduced using the dominance or dominant position criterion (Erikson 1984, p. 501; Korupp et al. 2002, p. 19), which establishes that the category which is highest internships, short term temporary work, non-contract work, or non-paid work in a family business) and never having experienced it (therefore having always had stable employment, defined by having had open-ended contracts or being self-employed). The absence of collinearity among predictors was checked.

The multinomial regression models estimate the effect of socio-demographic and trajectory variables on the probability of experiencing the most insecure labour market trajectories against the probability of experiencing the most stable trajectory. The estimation equation is given as follows (where TPR stands for the trajectory prior to the recession):

$$
\begin{aligned}
& \text { logit }(y=\text { precarious trajectory })=\log \left(\frac{\mathrm{P}(y=\text { precarious trajectory })}{\mathrm{P}(y=\text { stable trajectory })}\right) \\
&=\alpha+\beta \text { sex }+\beta \text { age }+\beta \text { place of birth }+\beta \text { parents' occ.status }+\beta \text { length TPR } \\
&+\beta \text { highest occ.status TPR }+\beta \text { stability TPR } \\
& \operatorname{logit}(y=\text { non-salaried trajectory })=\log \left(\frac{\mathrm{P}(y=\text { non-salaried trajectory })}{\mathrm{P}(y=\text { stable trajectory })}\right) \\
&=\alpha+\beta \text { sex }+\beta \text { age }+\beta \text { place of birth }+\beta \text { parents' occ.status }+\beta \text { length TPR } \\
&+\beta \text { highest occ.status TPR }+\beta \text { stability TPR } \\
& \text { logit }(y=\text { temporary empl.trajectory })=\log \left(\frac{\mathrm{P}(y=\text { temporary empl.trajectory })}{\mathrm{P}(y=\text { stable trajectory })}\right) \\
&=\alpha+\beta \text { sex }+\beta \text { age }+\beta \text { place of birth }+\beta \text { parents' occ.status }+\beta \text { length PRT } \\
&+\beta \text { highest occ.status TPR }+\beta \text { stability TPR }
\end{aligned}
$$

hierarchically (be it the mother or the father) should be chosen.

The second regression connects the different types of trajectories with variables showing the length and quality of the labour experience young people had at the start of the recession. ${ }^{10}$ Specifically, the variables considered in addition to those used in the first model are labour market experience (i.e., years in the labour market at the start of the crisis (as a continuous variable), the highest occupational status acquired during the period prior to the start of the recession, and the experience of unemployment or unstable employment also in the trajectory prior to the recession (shortened as stability in TPR). This latter variable is a dichotomous one, as we have distinguished between having experienced any event of unemployment or unstable employment (fixed term contracts, paid

\footnotetext{
${ }^{9}$ Hair et al. (2009, p. 524) warn against the selection of two-cluster solutions Despite the fact that it often involves the largest increase in heterogeneity, a two-cluster solution often has limited heuristic value and should only be selected if supported by strong theoretical reasoning.

10 When speaking of our analysis, and also in Tables 2, 3, 4, 7 and 8 we use the expression trajectory prior to the recession (TPR) to refer generally to these three variables.
}

A robustness check has been performed by reproducing the regression analysis only with the sub-population of young people up to 29 years of age. The effects of most of the predictors remain the same, except for place of birth and level of education, which do not exhibit statistical significance for explaining the trajectories when controlled by the variables of the nature of the pre-recession experience. Moreover, among this sub-population the length of the TPR is more important in the prediction of the non-salaried trajectory, while having experienced unemployment or unstable employment prior to the recession is not significant.

\section{Results and discussion}

\subsection{Results}

As mentioned in the methods section, the four cluster solution we have retained allows grouping internally homogeneous trajectories that, at the same time, have very different characteristics. This can be observed in Table 2, which presents a synopsis of the main characteristics of the four types of trajectories, including the most characteristic events of every type of trajectory, the kind of unemployment experienced in the trajectory (if any), and the socio-demographic characteristics of the 
Table 2 Synoptic table summarizing the main characteristics of the clusters

\begin{tabular}{|c|c|c|c|c|}
\hline & $\begin{array}{l}\text { Stable employment } \\
\text { trajectory }\end{array}$ & $\begin{array}{l}\text { Non-salaried employment } \\
\text { trajectory }\end{array}$ & $\begin{array}{l}\text { Temporary employment } \\
\text { trajectory }\end{array}$ & Precarious trajectory \\
\hline $\begin{array}{l}\text { Most characteristic events } \\
\text { experienced during the } \\
\text { recession (above-average) }\end{array}$ & Stable employment & Non-salaried employment & Temporary employment & $\begin{array}{l}\text { Short odd jobs } \\
\text { Unemployment } \\
\text { Inactivity }\end{array}$ \\
\hline $\begin{array}{l}\text { Experience of unemploy- } \\
\text { ment during the recession }\end{array}$ & Never unemployed & Never unemployed & $\begin{array}{l}\text { Short-term unemployment } \\
\text { (less than a year) }\end{array}$ & $\begin{array}{l}\text { Long-term unemployment } \\
\text { (one year or more) }\end{array}$ \\
\hline $\begin{array}{l}\text { Socio-demographic charac- } \\
\text { teristics of individuals in } \\
\text { the cluster }\end{array}$ & $\begin{array}{l}\text { 30-34 years old } \\
\text { Female } \\
\text { Education: Post-compulsory } \\
\text { secondary; higher } \\
\text { Born in Spain } \\
\text { Parents: Scientific, intellec- } \\
\text { tual and liberal profes- } \\
\text { sions }\end{array}$ & $\begin{array}{l}\text { 30-34 years old } \\
\text { Male } \\
\text { Born in Spain } \\
\text { Parents: Business owners } \\
\text { and managers }\end{array}$ & $\begin{array}{l}\text { 20-29 years old } \\
\text { Parents: Skilled and semi- } \\
\text { skilled workers }\end{array}$ & $\begin{array}{l}20-29 \text { years old } \\
\text { Education: Compulsory or less } \\
\text { Born abroad } \\
\text { Parents: Low-skilled workers }\end{array}$ \\
\hline
\end{tabular}

Source: Elaborated by authors

individuals in each group. ${ }^{11}$ We present them briefly in the following lines.

The first type, which we call the stable employment trajectory ( $44 \%$ of the cases in the sample) is characterised by job stability. Young people following this trajectory held stable employment for practically the entire time frame of our study. Therefore, the remaining employment situations have a negligible presence for those in this trajectory. Regarding their socio-demographic characteristics, young people with this trajectory are more likely to be older (30 to 34 years of age), have secondary or higher educational levels, be women, have been born in Spain, and be the children of individuals in scientific, intellectual or liberal professions.

The second type, which we call the precarious trajectory ( $26 \%$ of the cases) is characterised by unstable employment situations. Individuals with this trajectory experience long-term unemployment, which is combined with periods of inactivity and short odd jobs. In these cases, unemployment and temporality appear to be the common consequences of shared disadvantageous situations in the labour market, as suggested by Prieto and Pérez de Guzmán (2015). Young people with this type of trajectory are more likely to have low levels of education (at most having only finished compulsory education), to have been born outside of Spain, be under 30 years of age and be the children of low-skilled workers.

The third type, which we refer to as a temporary employment trajectory (20\% of the cases) is mainly characterised by the prevalence of temporary employment. Individuals with this trajectory have suffered more unemployment than young people with a stable or nonsalaried trajectory, although in contrast to the precarious trajectory, their unemployment is short-term, and not

\footnotetext{
11 Tables 5, 6 and 7 provide more detailed information on the distribution of these variables for every type of trajectory.
}

long-term. The majority of individuals with this type of trajectory are under 30 years of age and have parents in semi-skilled occupations and with middle levels of education (post-compulsory secondary studies).

The last type, which we refer to as a non-salaried employment trajectory (accounting for only a bit more than $10 \%$ of our sample), has as its defining characteristic that individuals were either self-employed or business owners for the majority of the time examined. Almost the totality of individuals in this group were never unemployed during the entire period of the crisis studied. Regarding their socio-demographic characteristics, individuals with this trajectory are more likely to be older (from 30 to 34 years of age), men, born in Spain, and children of managers and business owners.

Table 3 presents the coefficients from the two multinomial logistic regression models. The first includes only socio-demographic characteristics and the second adds the variables related to the trajectory prior to the recession (TPR). Comparing this second model with the first one, our initial finding is that, as expected, the explanatory power of the model increases when the three new variables related to the TPR of our sample of young people are incorporated. This can be seen in the higher $\mathrm{R}^{2}$ value of the second model. Nevertheless, even when introducing the TPR variables, most of the socio-demographic variables remain significant, particularly regarding the precarious and non-salaried trajectories. Only among the young people who experienced a trajectory of temporary employment does the introduction of TPR variables really introduce a relevant change in the significance of the socio-demographic variables. This suggests that sociodemographic characteristics might influence in a similar way the career path of young people with a precarious trajectory before and after the start of recession, and that the TPR has been more decisive in the likelihood of a young 
person having experienced a temporary employment trajectory during the crisis instead of the stable one.

The results of the multinomial logistic regressions also show that in comparison to the stable trajectory that we use as a reference, the precarious trajectory is positively associated with three socio-demographic features: being under 25 years of age, having been born outside of Spain, and having a low educational level (compulsory level as the highest). The second model shows that this trajectory is also related with having been employed before the crisis in, at most, semiskilled work and having suffered unemployment and unstable employment prior to the crisis.

The non-salaried employment trajectory is positively associated with the two socio-demographic features of being a man and having parents that are business owners, managers or technical employees, and is negatively associated with being between 25 and 29 years of age. Model 2 reveals that this trajectory is also associated with not having suffered unemployment or unstable employment prior to the crisis. It should be pointed out that in model 1 , this trajectory is associated with having a low level of education (compulsory or less), but a small change in its significance places this coefficient below the 95\% confidence level in model 2.

Finally, in model 2, the temporary employment trajectory is associated with the socio-demographic characteristic of having a low educational level and with three specific pre-crisis experiences: having low-skilled work, having suffered unemployment or unstable employment, and having had little prior experience in the labour market. The introduction in model 2 of these three characteristics carries with it the disappearance of the associations that exists in model 1 between this trajectory and being under 30 years of age and being born outside of Spain. It can be deduced, then, that it is not these two socio-demographic attributes that define its differences with those that have experienced a stable trajectory during the crisis.

\subsection{Discussion}

There are three main findings derived from these results. The first is that the existence of four major types of trajectories among young people confirms that the labour market for young people in Spain is characterised by an internal segmentation that goes beyond the stable and unstable divide-or primary and secondary segments. The first two trajectories, the stable and non-salaried employment trajectories, feature very low levels of unemployment and certain continuity in employment. In contrast, the other two trajectories, the temporary employment trajectory and the precarious trajectory, present much higher levels of unemployment and an important presence of instability. However, these two latter trajectories have important differences between them: individuals in the temporary employment trajectory faced primarily shortterm unemployment, and those who followed a precarious trajectory faced long-term unemployment and greater discontinuity and instability in employment. The existence in Spain of different layers within the unstable (or secondary) segment has been revealed by previous research, both for the pre-crisis period (Alós 2008; Verd and López-Andreu 2012) and crisis period (Castelló et al. 2013; López-Andreu and Verd 2016). Our results confirm these previous findings from a perspective based on the analysis of employment trajectories, and show its link with the presence of very different forms of unemployment.

Our second finding points to the importance of the socio-demographic characteristics of young people in regard to the types of trajectories experienced during the crisis. Thus, being in the youngest cohort and being born outside of Spain makes it more likely to have had the precarious trajectory. Having a low educational level makes it more likely that a young person will have followed the two types of trajectories that are more unstable and where unemployment is more frequent. These results confirm the results of other cross-sectional analyses and show a pattern of continuity with the period prior to the crisis regarding the trajectories of low-educated workers, immigrants and young persons under 25 years of age (García-Pérez and Muñoz-Bullón 2011; Verd and LópezAndreu 2012; Rocha 2012a, b; Alós 2015; Alós and Lope 2015). Moreover, these results reveal that the dynamics of an ethno-stratification of the labour market (Cachón 2009) and the family transmission of (dis)advantages (Serracant 2012; O'Reilly et al. 2015) have continued structuring young people's labour market experiences during the crisis. However, our results also show the emergence of an intermediate segment placed between the stable and the most precarious one that has been also hit by unemployment, and with many socio-demographic characteristics that are not significantly different from those of young people with a stable trajectory. The analysis of the TPR (see below) in this kind of career path becomes critical to understand what could have caused their unemployment during the Great Recession. Regarding the trajectories that were not affected by unemployment, being a man, being between 25 and 29 years of age and having parents that are managers, business owners, middle management or technical employees correlates with having experienced the non-salaried trajectory. Thus, a young person's family background seems to be connected to the type of trajectory developed during the crisis. López-Andreu and Verd (2016), using a different data set, also reached a similar conclusion. These authors point out that the role of family background seems to be more important during the recession period than in the past in terms of differentiating between trajectories of stability and temporary 


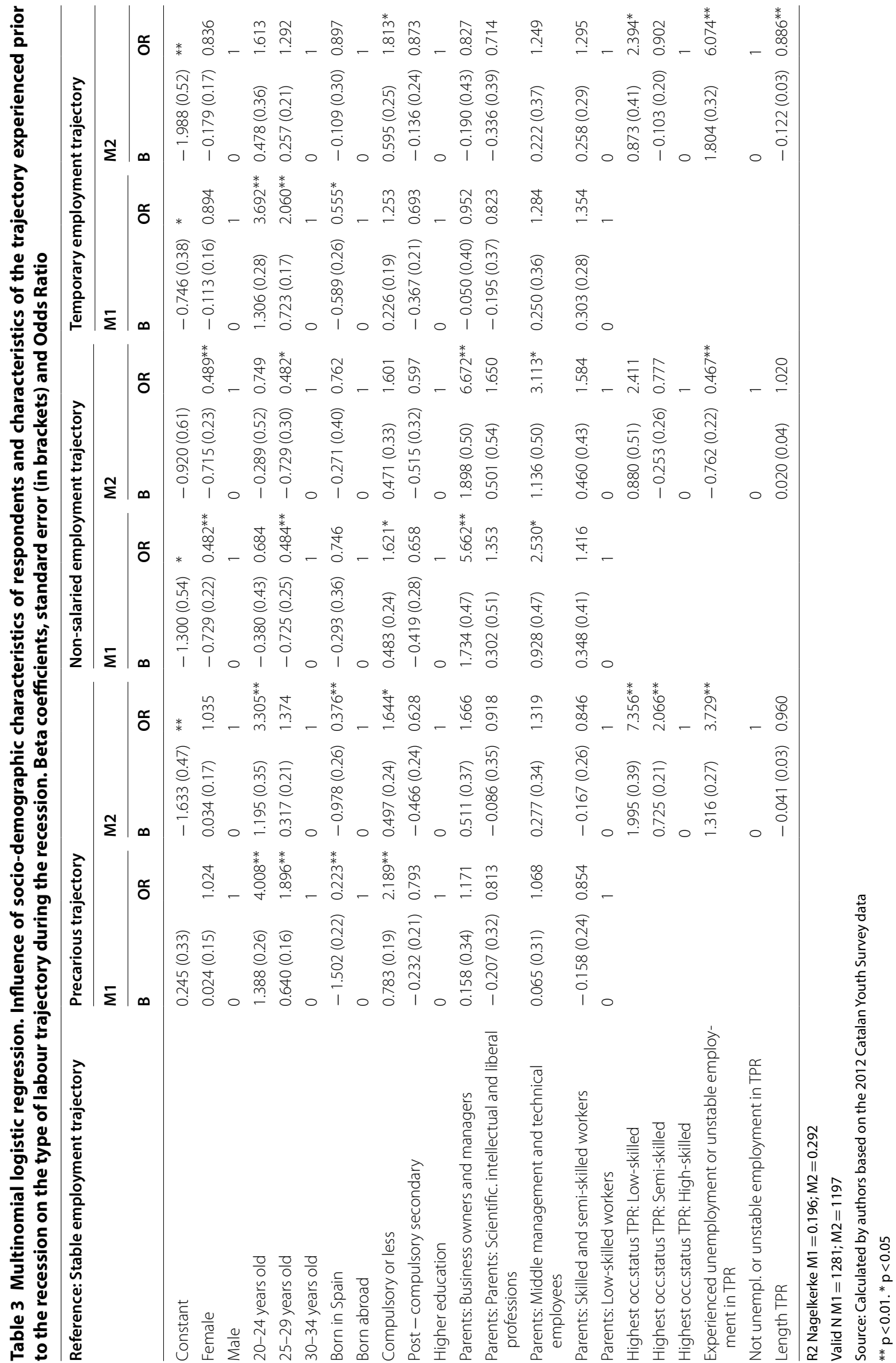


employment. Although the stable trajectory has been taken as reference, it is worth mentioning that this trajectory presents the most significant differences with the precarious trajectory, showing once again the association between socio-demographic characteristics (what we have called social factors) and the specific segment where the labour market trajectory unfolds. ${ }^{12}$

The third finding is related to the connexion of TPR with the trajectories young people experienced during the crisis. Results show an association between having been employed in low-skilled and semi-skilled jobs before the crisis and the two trajectories most affected by unemployment and instability. Likewise, having suffered unemployment and unstable employment before the crisis is associated with experiencing the two types of trajectories most affected by unemployment and job instability during the crisis. Therefore, we can infer from our results that in a context of economic recession workers being in a situation of unstable and low-skilled employment were the first to be dismissed, who were also, possibly, those in the weakest positions inside firms (Hernanz 2003). These results suggest that lay-offs have not been carried out independently of the previous career path and therefore continuity in the possibilities of being trapped in situations of instability and unemployment over time (Bruno et al. 2012; Rocha 2012a) for certain groups of young workers in Spain. This tendency is particularly strong in Spain due to the low rates of transition from temporary to stable employment, and the high rates of transition between temporary employment and unemployment or inactivity (Belvis and Benach 2014).

However, the comments above should be qualified taking into account the negative correlation between years of employment experience and belonging to the temporary employment trajectory. The more experience in the labour market a young person has the less likely he or she is to fall into a temporary employment trajectory, and the more likely he or she is to have a more stable itinerary. This suggests that some young people that began working with temporary contracts moved on to situations of stable employment as they accumulated enough experience in the labour market before the start of the crisis, while those with less experience were more likely to lose their jobs. Thus, the argument that the institutional design of school-towork transitions in Spain produced work experience gaps (Pastore 2015; Pastore and Giuliani 2015) that affected the likelihood of being laid off with the onset of the crisis is

\footnotetext{
${ }^{12}$ While the objective of the article was not analysing the effect of recession on the social mobility of young people with a more advantageous origin, it is worth noting that the results of our analysis (Tables 2 and 3, and also 7) show that the individuals in the non-salaried trajectory are characterised by being a man and the offspring of business owners and managers, while the individuals in the stable trajectory are characterised by being a woman, the offspring of scientific, intellectual and liberal professionals and having higher education. These results seem to hint at the gendered pattern of the way social mobility occurs in Spain (Salido 2001).
}

reinforced by our results. For the years prior to the crisis, Quintini et al. (2007, p. 8) found that accumulated years of work have great importance for an individual in finding their first stable position after entering the labour market. In Spain, the average time for doing so was six years for the period they examined in their study (from 1994 to 2000), which is the longest period among the western countries of the EU. However, employment experience did not protect young people from having a precarious trajectory, revealing very different employment prospects for this latter group. This suggests that the combination of factors related to previous employment experience and social factors (related to individuals' social profile) define whether temporary contracts represent a way of accessing a more stable job or not. In other words, the most vulnerable profiles, which are placed in the most precarious segment of the labour market, have greater difficulty making their experience count.

\section{Conclusions}

As stated in the introduction, the primary objective of this article was to identify, from a sociological perspective, what determinants are associated with youth unemployment in Spain during the Great Recession, addressing both socio-demographic characteristics as well as factors connected to career paths. Our approach has some limitations, as the data we have used refers only to young people in Catalonia. In addition, our analysis does not take fully into account the impact of early labour market experiences on current labour market status, this could be carried out in future research. However we believe our approach based on the analysis of labour market trajectories has produced an improved and more detailed picture of how Spanish young people have been affected by unemployment and instability during the crisis.

First of all, our results indicate that during the period we have analysed (October 2007 to April 2012), there was not a polarisation in the trajectories of young people between those who were employed and those who were unemployed. Rather, we can talk of a segmentation in four types of trajectories, or a segmented polarisation, in which two trajectories, the stable and non-salaried employment trajectories, feature very low levels of unemployment while the other two trajectories, the temporary employment trajectory and the precarious trajectory, present much higher levels of unemployment and instability. However, there are important differences between the latter two: those with the temporary employment trajectory faced primarily short-term unemployment, and those who followed a precarious trajectory faced long-term unemployment and greater discontinuity and unstable employment.

This finding hints at the existence of different layers of labour market segmentation in Spain, at least for the period of recession, and identifies an intermediate segment 
with a strong presence of unstable employment that is not linked to the most vulnerable social profiles nor to entrapment in low-skilled jobs-considered characteristics of the secondary segment of the labour market, as in Spain (Bernardi and Garrido 2008) or Italy (Barbieri and Scherer 2009). This more complex and nuanced picture of labour market segmentation is very helpful to explain how different determinants (that we have grouped in what we refer to as social factors and career factors) affect the trajectories of young workers during the Great Recession. Regarding the effect of social factors, i.e., the relation between socio-demographic characteristics and type of trajectory, our findings show that the trajectory characterised by the highest levels of long-term unemployment is associated with the most vulnerable social profiles-the youngest members of the working population, immigrants and young people with low educational levels. Thus, our analysis helps to identify the social profile of the young workers among whom long-term unemployment has spread during the recession (De la Rica 2014). The risk for this profile to enter into a situation of labour market exclusion (Rocha 2012b; ILO 2014) seems real, given the worsening of their already poor labour market prospects caused by the recession. Moreover, our results reveal that socio-demographic characteristics are less important in relation to trajectories with short-term unemployment, compared to those of young people with a stable employment trajectory.

Regarding the role of career factors, i.e. of pre-crisis employment experiences, we find that both young people with precarious trajectories and those with temporary employment trajectories had pre-crisis careers characterised by low-skilled and unstable employment, and also by the presence of unemployment. Nevertheless, and interestingly, the results show that only the temporary employment trajectory is associated with having had a short pre-crisis employment experience, which contrasts with the longer labour market experience of young people with a precarious trajectory. Therefore, it appears that in a context of economic recession, workers with a record of unstable and low-skilled employment are more likely to be unemployed, but it also seems that the lack of experience has played a role in that less vulnerable young people were laid-off. We can conclude, then, that the experience gap argument (Pastore 2015; Pastore and Giuliani 2015 ) is useful to explain only the kind of trajectory where non-vulnerable young people (attending to their social profile) are involved, as the most vulnerable profiles seemed to be trapped in a circle of long-term unemployment and short odd jobs with the onset of recession. This finding also shows the great importance that experience has in Spain for some young workers-those with post-compulsory education-to get out of the unstable segment of the labour market.

These results showing an interaction between sociodemographic characteristics and factors related to employment experience pose interesting implications for policy making. First of all, they imply that youth unemployment policies have to be conceived in connection with the characteristics of the career path and the segment where the employment trajectory is developed. Furthermore, they seem to show that the rationale behind the experience of unemployment for different profiles of young peopleconnected in our analysis to the precarious and temporary employment trajectories-is different, and therefore the actions to be taken should also be different. While limiting the use of temporary contracts or providing opportunities to acquire skill-relevant experience could be a way to fight against unemployment for those young people with postcompulsory education, this does not seem to be a solution for most vulnerable profiles. More comprehensive measures seem to be necessary to address the condition of young people whose trajectories include higher levels of long-term unemployment, as their situation appears to be the result of being trapped in the most precarious segments of the labour market. The question this raises is whether the policies to address unemployment being carried out in Spain during the Great Recession (and in fact, all of Europe, given the similarity in policies across the EU) are going to change these structural determinants affecting these most vulnerable groups of young people within the labour market.

\section{Authors' contributions}

$J M V, O B$, and $M B$ were equally involved in the analysis of data and writing of the article. However, JMV and $\mathrm{OB}$ concentrated on the literature review and writing of sections 1 and 2, and MB concentrated on generating the data, data processing and writing of section 3 . Sections 4 and 5 were written jointly by the three authors. All authors read and approved the final manuscript.

\section{Author details}

${ }^{1}$ Centre d'Estudis Sociologics Sobre la Vida Quotidiana i el Treball (Sociological Research Centre on Everyday Life and Work-QUIT), Institut d'Estudis del Treball (Institute for Labour Studies-IET), Universitat Autonoma de Barcelona, Building B. Campus of the Universitat Autonoma of Barcelona, 08193 Cerdanyola del Vallés, Barcelona, Spain. ${ }^{2}$ Health Inequalities Research Group-Employment Conditions Network (GREDS-EMCONET); Johns Hopkins University-Universitat Pompeu Fabra Public Policy Center; Department of Political and Social Sciences, Universitat Pompeu Fabra, Campus Ciutadella-Universitat Pompeu Fabra, Edifici Mercè Rodoreda 24. Ramon Trias i Fargas 25-27, 08005 Barcelona, Spain.

\section{Acknowledgements}

We would like to thank the Catalan Youth Observatory for letting us use the data from the Catalan Youth Survey 2012. We would particularly like to thank Pau Serracant for his help and for encouraging us to send our study to the Journal of Labour Market Research in response to their call for research on Youth unemployment in Europe. We are also grateful to two anonymous referees for their comments, which enabled us to greatly improve the quality of our paper. It goes without saying that any errors in this article are the sole responsibility of the authors.

Competing interests

The authors declare that they have no competing interests.

\section{Appendix}

See Fig. 1, Tables 4, 5, 6, 7 and 8. 


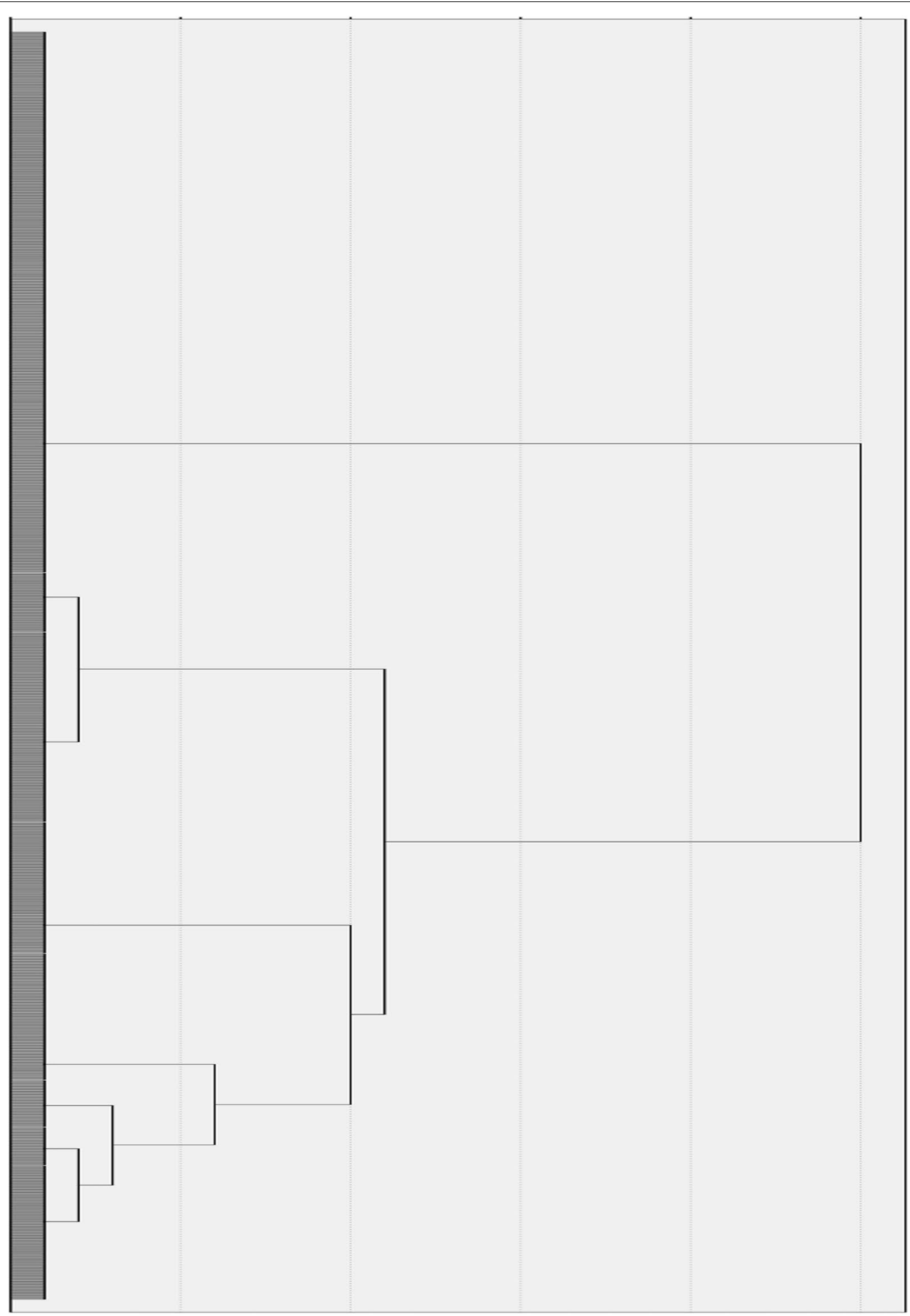

Fig. 1 Dendrogram of the clustering aggregation procedure based on Ward's method (Source: Calculated by authors based on the 2012 Catalan Youth Survey data) 
Table 4 Summary statistics for the variables in the research

Percentage of the trajectory unemployed (mean, sd)

$6.24(16.55)$

Percentage of the trajectory inactive (mean, sd)

$5.26(18.50)$

Percentage of the trajectory non-salaried (mean, sd)

$9.47(27.62)$

Percentage of the trajectory in stable employment (mean, sd)

$46.58(44.28)$

Percentage of the trajectory in temporary employment (mean, sd)

$18.25(31.03)$

Percentage of the trajectory in short odd jobs (mean, sd)

$10.95(27.97)$

Percentage of the trajectory in informal employment (mean, sd)

$1.50(8.59)$

Type of trajectory

Stable employment trajectory

$43.6 \%$

Precarious trajectory

$26.4 \%$

Temporary employment trajectory

$19.7 \%$

Non-salaried employment trajectory

Sex

Female

Male

Age group

20-24 years old

$10.4 \%$

25-29 years old

$34.6 \%$

30-34 years old

$55.0 \%$

National origin

Born in Spain

$85.2 \%$

Immigrant (born abroad)

$14.8 \%$

Education

Compulsory or less

$34.0 \%$

Post-compulsory secondary

$22.6 \%$

Higher

$43.4 \%$

Parents' highest occupational status

Business owners and managers

Scientific, intellectual and liberal professions

$10.7 \%$

Middle management and technical employees

$11.2 \%$

Skilled and semi-skilled workers

$57.8 \%$

Low-skilled workers

$10.8 \%$

Length TPR: Years of experience at the start of the crisis (mean, sd)

\section{Highest occupational status acquired TPR}

Low-skilled job

Skilled and semi-skilled job

$52.8 \%$

High-skilled job (includes employment of middle management and technical empl., scientific, intellectual and liberal professions, business owners and managers)

\section{Stability in TPR}

Experience of unemployment or unstable employment TPR 
Table 5 Number of individuals and average length of time in stable employment, non-salaried employment, unemployment, inactivity, short odd jobs, temporary employment and informal employment by type of trajectory

\begin{tabular}{|c|c|c|c|c|c|c|c|}
\hline & $\begin{array}{l}\text { Stable } \\
\text { employment }\end{array}$ & $\begin{array}{l}\text { Non-salaried } \\
\text { employment }\end{array}$ & Unemploy-ment & Inactivity & Short odd jobs & $\begin{array}{l}\text { Temporary } \\
\text { employment }\end{array}$ & $\begin{array}{l}\text { Informal } \\
\text { employment }\end{array}$ \\
\hline \multicolumn{8}{|c|}{ Stable employment trajectory } \\
\hline Mean & 93.64 & 0.12 & 1.21 & 0.95 & 0.18 & 3.10 & 0.56 \\
\hline N & 577 & 577 & 577 & 577 & 577 & 577 & 577 \\
\hline Sd & 11.05 & 1.51 & 4.64 & 5.01 & 1.65 & 7.89 & 3.69 \\
\hline \multicolumn{8}{|c|}{ Precarious trajectory } \\
\hline Mean & 6.68 & 1.13 & 18.19 & 15.95 & 40.97 & 7.95 & 3.16 \\
\hline N & 350 & 350 & 350 & 350 & 350 & 350 & 350 \\
\hline Sd & 13.85 & 5.35 & 27.41 & 31.73 & 41.58 & 14.61 & 14.45 \\
\hline \multicolumn{8}{|c|}{ Non-salaried employment trajectory } \\
\hline Mean & 7.38 & 88.36 & 0.82 & 0.35 & 0.08 & 2.09 & 0.89 \\
\hline N & 136 & 136 & 136 & 136 & 136 & 136 & 136 \\
\hline Sd & 17.37 & 20.18 & 4.23 & 2.99 & 1.44 & 7.64 & 4.04 \\
\hline \multicolumn{8}{|c|}{ Temporary employment trajectory } \\
\hline Mean & 16.25 & 0.29 & 4.16 & 2.98 & 0.14 & 74.14 & 1.66 \\
\hline N & 260 & 260 & 260 & 260 & 260 & 260 & 260 \\
\hline Sd & 22.50 & 1.92 & 7.82 & 10.82 & 1.68 & 22.97 & 7.14 \\
\hline \multicolumn{8}{|l|}{ Total } \\
\hline Mean & 46.58 & 9.47 & 6.24 & 5.26 & 10.95 & 18.25 & 1.50 \\
\hline N & 1322 & 1322 & 1322 & 1322 & 1322 & 1322 & 1322 \\
\hline Sd & 44.26 & 27.62 & 16.55 & 18.50 & 27.97 & 31.03 & 8.59 \\
\hline
\end{tabular}

Source: Calculated by authors based on the 2012 Catalan Youth Survey data

Table 6 Frequencies of length of the longest unemployment spell experienced by type of trajectory

\begin{tabular}{|c|c|c|c|c|}
\hline & Never unemployed & $\begin{array}{l}\text { Short-term unemployment (less } \\
\text { than a year) }\end{array}$ & $\begin{array}{l}\text { Long-term unemployment (one } \\
\text { year or more) }\end{array}$ & Total \\
\hline \multicolumn{5}{|c|}{ Stable employment trajectory } \\
\hline $\mathrm{N}$ & 528 & 39 & 10 & 577 \\
\hline$\%$ column & 51.3 & 25.5 & 7.2 & 43.6 \\
\hline Adjusted residual & 10.5 & -4.8 & -9.2 & \\
\hline \multicolumn{5}{|l|}{ Precarious trajectory } \\
\hline N & 194 & 40 & 116 & 350 \\
\hline$\%$ column & 18.8 & 26.1 & 83.5 & 26.5 \\
\hline Adjusted residual & -11.8 & -0.1 & 16.1 & \\
\hline \multicolumn{5}{|c|}{ Non-salaried employment trajectory } \\
\hline N & 127 & 6 & 3 & 136 \\
\hline$\%$ column & 12.3 & 3.9 & 2.2 & 10.3 \\
\hline Adjusted residual & 4.6 & -2.8 & -3.3 & \\
\hline \multicolumn{5}{|c|}{ Temporary employment trajectory } \\
\hline N & 181 & 68 & 10 & 259 \\
\hline$\%$ column & 17.6 & 44.4 & 7.2 & 19.6 \\
\hline Adjusted residual & -3.5 & 8.2 & -3.9 & \\
\hline \multicolumn{5}{|l|}{ Total } \\
\hline $\mathrm{N}$ & 1030 & 153 & 139 & 1322 \\
\hline$\%$ column & $100.0 \%$ & $100.0 \%$ & $100.0 \%$ & $100.0 \%$ \\
\hline
\end{tabular}

V Cramer $=0.359(p<0.001)$

Source: Calculated by authors based on the 2012 Catalan Youth Survey data 
Table 7 Characteristics of age, sex, educational level, national origin, parents' highest occupational status and characteristics of the trajectory prior to the recession by type of trajectory

\begin{tabular}{|c|c|c|c|c|c|}
\hline & $\begin{array}{l}\text { Stable employment } \\
\text { trajectory }\end{array}$ & $\begin{array}{l}\text { Non-salaried employment } \\
\text { trajectory }\end{array}$ & $\begin{array}{l}\text { Temporary employment } \\
\text { trajectory }\end{array}$ & Precarious trajectory & Total \\
\hline \multicolumn{6}{|l|}{ Age group } \\
\hline \multicolumn{6}{|c|}{$20-24$ years old } \\
\hline$\%$ row & 21.9 & 5.8 & 26.3 & 46.0 & \multirow[t]{2}{*}{100} \\
\hline Adjusted res. & -5.4 & -1.8 & 2.1 & 5.5 & \\
\hline \multicolumn{6}{|c|}{$25-29$ years old } \\
\hline$\%$ row & 38.9 & 5.5 & 24.9 & 30.8 & \multirow[t]{2}{*}{100} \\
\hline Adjusted res. & -2.5 & -4.2 & 3.5 & 2.6 & \\
\hline \multicolumn{6}{|c|}{$30-34$ years old } \\
\hline \% row & 50.6 & 14.2 & 15.1 & 20.1 & \multirow[t]{2}{*}{100} \\
\hline Adjusted res. & 5.7 & 5.1 & -4.6 & -5.8 & \\
\hline \multicolumn{6}{|l|}{$\operatorname{sex}$} \\
\hline \multicolumn{6}{|l|}{ Female } \\
\hline$\%$ row & 47.4 & 7.3 & 19.4 & 26.0 & \multirow[t]{2}{*}{100} \\
\hline Adjusted res. & 2.6 & -3.4 & -0.3 & -0.4 & \\
\hline \multicolumn{6}{|l|}{ Male } \\
\hline$\%$ row & 40.3 & 12.9 & 19.9 & 26.9 & \multirow[t]{2}{*}{100} \\
\hline Adjusted res. & -2.6 & 3.4 & 0.3 & 0.4 & \\
\hline \multicolumn{6}{|l|}{ Education } \\
\hline \multicolumn{6}{|c|}{ Compulsory or less } \\
\hline$\%$ row & 30.4 & 10.9 & 21.2 & 37.5 & \multirow[t]{2}{*}{100} \\
\hline Adjusted res. & -6.9 & 0.5 & 0.9 & 6.6 & \\
\hline \multicolumn{6}{|c|}{ Post-compulsory secondary } \\
\hline$\%$ row & 50.7 & 7.8 & 18.2 & 23.3 & \multirow[t]{2}{*}{100} \\
\hline Adjusted res. & 2.8 & -1.7 & -0.8 & -1.3 & \\
\hline \multicolumn{6}{|l|}{ Higher } \\
\hline$\%$ row & 50.3 & 11.2 & 19.4 & 19.1 & \multirow[t]{2}{*}{100} \\
\hline Adjusted res. & 4.3 & 0.9 & -0.3 & -5.2 & \\
\hline \multicolumn{6}{|l|}{ National origin } \\
\hline \multicolumn{6}{|l|}{ Born in Spain } \\
\hline$\%$ row & 47.1 & 11.0 & 20.2 & 21.8 & \multirow[t]{2}{*}{100} \\
\hline Adjusted res. & 6.1 & 2.1 & 1.1 & -9.3 & \\
\hline Immigrant & & & & & \\
\hline$\%$ row & 23.9 & 6.1 & 16.8 & 53.3 & 100 \\
\hline adjusted res. & -6.1 & -2.1 & -1.1 & 9.3 & \\
\hline Parents'highes & hal status & & & & \\
\hline Business own & nagers & & & & \\
\hline$\%$ row & 36.4 & 24.8 & 14.0 & 24.8 & 100 \\
\hline Adjusted res. & -1.6 & 5.5 & -1.7 & -0.5 & \\
\hline Scientific, inte & d liberal professions & & & & \\
\hline$\%$ row & 52.9 & 8.7 & 14.5 & 23.9 & 100 \\
\hline Adjusted res. & 2.5 & -0.7 & -1.7 & -0.8 & \\
\hline Middle mana & technical employees & & & & \\
\hline$\%$ row & 43.1 & 13.9 & 18.1 & 25.0 & 100 \\
\hline Adjusted res. & 0 & 1.5 & -0.6 & -0.5 & \\
\hline Skilled and se & vorkers & & & & \\
\hline$\%$ row & 43.4 & 8.5 & 23.1 & 25.1 & 100 \\
\hline Adjusted res. & 0.3 & -2.6 & 3.2 & -1.5 & \\
\hline
\end{tabular}


Table 7 (continued)

\begin{tabular}{|c|c|c|c|c|c|}
\hline & $\begin{array}{l}\text { Stable employment } \\
\text { trajectory }\end{array}$ & $\begin{array}{l}\text { Non-salaried employment } \\
\text { trajectory }\end{array}$ & $\begin{array}{l}\text { Temporary employment } \\
\text { trajectory }\end{array}$ & Precarious trajectory & Total \\
\hline \multicolumn{6}{|c|}{ Low-skilled workers } \\
\hline$\%$ row & 37.1 & 5.7 & 16.4 & 40.7 & 100 \\
\hline Adjusted res. & -1.5 & -1.9 & -1.1 & 4.0 & \\
\hline \multicolumn{6}{|l|}{ Stability in TPR } \\
\hline \multicolumn{6}{|c|}{ Experience of unemployment or unstable employment } \\
\hline \% row & 40.4 & 7.5 & 22.4 & 29.7 & 100 \\
\hline Adjusted res. & -5.4 & -7.5 & 5.6 & 6.1 & \\
\hline \multicolumn{6}{|c|}{ No experience of unemployment or unstable employment } \\
\hline$\%$ row & 60.6 & 24.4 & 5.6 & 9.4 & 100 \\
\hline Adjusted res. & 5.4 & 7.5 & -5.6 & -6.1 & \\
\hline \multicolumn{6}{|c|}{ Highest occupational status acquired TPR } \\
\hline \multicolumn{6}{|c|}{ Low-skilled job } \\
\hline$\%$ row & 17.6 & 11.0 & 22.0 & 49.5 & 100 \\
\hline Adjusted res. & -5.5 & 0.0 & 0.4 & 6.1 & \\
\hline \multicolumn{6}{|c|}{ Skilled and semi-skilled job } \\
\hline$\%$ row & 44.3 & 8.6 & 19.1 & 28.0 & 100 \\
\hline Adjusted res. & -0.8 & -2.8 & -1.0 & 3.9 & \\
\hline \multicolumn{6}{|c|}{ High-skilled job } \\
\hline$\%$ row & 51.8 & 14.0 & 21.3 & 12.8 & 100 \\
\hline Adjusted res. & 3.7 & 2.8 & 0.8 & -7.2 & \\
\hline \multicolumn{6}{|l|}{ Length TPR } \\
\hline \multicolumn{6}{|l|}{$0-2$ years } \\
\hline$\%$ row & 33.9 & 6.1 & 27.7 & 32.3 & 100 \\
\hline Adjusted res. & -4.5 & -3.1 & 4.7 & 3.0 & \\
\hline \multicolumn{6}{|l|}{$3-5$ years } \\
\hline$\%$ row & 48.0 & 11.3 & 15.5 & 25.1 & 100 \\
\hline Adjusted res. & 1.9 & 0.7 & -2.3 & -0.6 & \\
\hline \multicolumn{6}{|c|}{6 years or more } \\
\hline$\%$ row & 47.3 & 12.3 & 16.9 & 23.5 & 100 \\
\hline Adjusted res. & 2.4 & 2.2 & -2.2 & -2.2 & \\
\hline \multicolumn{6}{|l|}{ Total } \\
\hline \% row & 43.6 & 10.3 & 19.7 & 26.4 & 100 \\
\hline
\end{tabular}

Percentages and adjusted residuals

Calculated by authors based on the 2012 Catalan Youth Survey data 
Table 8 Multinomial logistic regression for the subpopulation of 20-29 years old (N M1 = 584 M2=545)

\begin{tabular}{|c|c|c|c|c|}
\hline \multirow[t]{2}{*}{ Reference: stable employment trajectory } & \multicolumn{2}{|l|}{ M1 } & \multicolumn{2}{|l|}{ M2 } \\
\hline & B & OR & B & OR \\
\hline \multicolumn{5}{|l|}{ Precarious trajectory } \\
\hline Constant & $0.597(0.47)$ & & $-1.898(0.69)$ & $* *$ \\
\hline Female & $0.357(0.23)$ & 1.429 & $0.368(0.26)$ & 1.445 \\
\hline Male & 0 & 1 & 0 & 1 \\
\hline $20-24$ years old & $0.821(0.26)$ & $2.273^{* *}$ & $0.759(0.33)$ & $2.136^{*}$ \\
\hline $25-29$ years old & 0 & 1 & 0 & 1 \\
\hline Born in Spain & $-1.295(0.30)$ & $0.274^{*}$ & $-0.561(0.35)$ & 0.571 \\
\hline Born abroad & 0 & 1 & 0 & 1 \\
\hline Compulsory or less & $0.314(0.28)$ & 1.369 & $0.397(0.35)$ & 1.487 \\
\hline Post-compulsory secondary & $0.332(0.29)$ & 1.394 & $0.336(0.34)$ & 1.399 \\
\hline Higher education & 0 & 1 & 0 & 1 \\
\hline Parents: business owners and managers & $0.482(0.48)$ & 1.619 & $0.659(0.53)$ & 1.933 \\
\hline Parents: scientific. intellectual and liberal professions & $-0.238(0.48)$ & 0.788 & $-0.223(0.52)$ & 0.800 \\
\hline Parents: middle management and technical employees & $0.337(0.50)$ & 1.400 & $0.933(0.56)$ & 2.541 \\
\hline Parents: skilled and semi-skilled workers & $-0.263(0.35)$ & 0.769 & $-0.347(0.38)$ & 0.707 \\
\hline Parents: low-skilled workers & 0 & 1 & 0 & 1 \\
\hline Highest occup. status TPR: low-skilled & & & $2.060(0.55)$ & $7.845^{*}$ \\
\hline Highest occup. status TPR: semi-skilled & & & $0.645(0.30)$ & 1.906 \\
\hline Highest occup. status TPR: high-skilled & & & 0 & 1 \\
\hline Experienced unemployment or unstable employment in TPR & & & $1.692(0.41)$ & $5.429^{*}$ \\
\hline Not unemployment or unstable employment in TPR & & & 0 & 1 \\
\hline Length TPR & & & $-0.109(0.06)$ & 0.897 \\
\hline \multicolumn{5}{|l|}{ Non-salaried employment trajectory } \\
\hline Constant & $-4.683(1.66)$ & ** & $-8.227(2.01)$ & ** \\
\hline Female & $-1.413(0.61)$ & $0.243^{*}$ & $-1.216(0.67)$ & 0.296 \\
\hline Male & 0 & 1 & 0 & 1 \\
\hline 20-24 years old & $0.238(0.48)$ & 1.269 & $2.116(0.75)$ & $8.294^{*}$ \\
\hline $25-29$ years old & 0 & 1 & 0 & 1 \\
\hline Born in Spain & $2.052(1.46)$ & 7.783 & $2.023(1.49)$ & 7.562 \\
\hline Born abroad & 0 & 1 & 0 & 1 \\
\hline Compulsory or less & $1.539(0.70)$ & $4.659^{*}$ & $-0.031(0.84)$ & 0.970 \\
\hline Post-compulsory secondary & $1.733(0.72)$ & $5.657^{*}$ & $1.142(0.77)$ & 3.134 \\
\hline Higher education & 0 & 1 & 0 & 1 \\
\hline Parents: business owners and managers & $1.224(0.77)$ & 3.400 & $2.109(0.89)$ & 8.241 \\
\hline Parents: scientific, intellectual and liberal professions & $-0.198(0.96)$ & 0.821 & $0.844(1.05)$ & 2.325 \\
\hline Parents: middle management and technical employees & $-0.086(0.96)$ & 0.918 & $1.402(1.08)$ & 4.065 \\
\hline Parents: skilled and semi-skilled workers & $-0.356(0.65)$ & 0.701 & $0.222(0.72)$ & 1.248 \\
\hline Parents: low-skilled workers & 0 & 1 & 0 & 1 \\
\hline Highest occup. status TPR: low-skilled & & & $2.878(0.87)$ & $17.776^{*}$ \\
\hline Highest occup. status TPR: semi-skilled & & & $1.087(0.66)$ & 2.964 \\
\hline Highest occup. status TPR: high-skilled & & & 0 & 1 \\
\hline Experienced unemployment or unstable employment in TPR & & & $0.463(0.52)$ & 1.589 \\
\hline Not unemployment or unstable employment in TPR & & & 0 & 1 \\
\hline Length TPR & & & $0.441(0.15)$ & $1.554^{*}$ \\
\hline \multicolumn{5}{|l|}{ Temporary employment trajectory } \\
\hline Constant & $-0.454(0.52)$ & & $-3.153(0.81)$ & ** \\
\hline Female & $0.275(0.24)$ & 1.316 & $0.218(0.26)$ & 1.244 \\
\hline Male & 0 & 1 & 0 & 1 \\
\hline
\end{tabular}


Table 8 (continued)

\begin{tabular}{|c|c|c|c|c|}
\hline \multirow[t]{2}{*}{ Reference: stable employment trajectory } & \multicolumn{2}{|l|}{ M1 } & \multicolumn{2}{|l|}{ M2 } \\
\hline & B & OR & B & OR \\
\hline 20-24 years old & $0.569(0.28)$ & 1.766 & $0.125(0.35)$ & 1.134 \\
\hline $25-29$ years old & 0 & 1 & 0 & 1 \\
\hline Born in Spain & $-0.364(0.35)$ & 0.695 & $0.354(0.40)$ & 1.425 \\
\hline Born abroad & 0 & 1 & 0 & 1 \\
\hline Compulsory or less & $0.394(0.28)$ & 1.482 & $0.619(0.35)$ & 1.857 \\
\hline Post-compulsory secondary & $0.144(0.31)$ & 1.155 & $0.176(0.35)$ & 1.193 \\
\hline Higher education & 0 & 1 & 0 & 1 \\
\hline Parents: business owners and managers & $0.026(0.56)$ & 1.026 & $-0.176(0.60)$ & 0.838 \\
\hline Parents: scientific, intellectual and liberal professions & $-0.255(0.54)$ & 0.775 & $-0.651(0.58)$ & 0.522 \\
\hline Parents: middle management and technical employees & $0.309(0.54)$ & 1.363 & $0.819(0.60)$ & 2.268 \\
\hline Parents: skilled and semi-skilled workers & $0.037(0.38)$ & 1.038 & $-0.021(0.41)$ & 0.979 \\
\hline Parents: low-skilled workers & 0 & 1 & 0 & 1 \\
\hline Highest occup. status TPR: low-skilled & & & $1.781(0.56)$ & $5.939^{*}$ \\
\hline Highest occup. status TPR: semi-skilled & & & $0.331(0.30)$ & 1.393 \\
\hline Highest occup. status TPR: high-skilled & & & 0 & 1 \\
\hline Experienced unemployment or unstable employment in TPR & & & $2.680(0.55)$ & $14.591^{*}$ \\
\hline Not unemployment or unstable employment in TPR & & & 0 & 1 \\
\hline Length TPR & & & $-0.186(0.06)$ & $0.830^{*}$ \\
\hline
\end{tabular}

Influence of socio-demographic characteristics of respondents and characteristics of the trajectory experienced prior to the recession on the type of labour trajectory. Beta coefficients, standard error (in brackets) and Odds Ratio

R2 Nagelkerke $\mathrm{M} 1=0.163 ; \mathrm{M} 2=0.322$

Source: Calculated by authors based on the 2012 Catalan Youth Survey data

** $\mathrm{p}<0.01, * \mathrm{p}<0.05$

\section{Publisher's Note}

Springer Nature remains neutral with regard to jurisdictional claims in published maps and institutional affiliations.

Received: 28 February 2017 Accepted: 14 February 2019

Published online: 05 March 2019

\section{References}

Alós, R:: Segmentación de los mercados de trabajo y relaciones laborales. El sindicalismo ante la acción colectiva. Cuadernos de Relaciones Laborales 26(1), 123-148 (2008)

Alós, R.: Desempleo y empleo durante la crisis. In: Miguélez, F. (coord.) Diagnóstico socioeconómico sobre las políticas de empleo en España, 2012-2014. Universitat Autònoma de Barcelona, Bellaterra (Cerdanyola del Vallès). http://ddd.uab.cat/record/142884 (2015)

Alós, R., Lope, A.: El desempleo y sus consecuencias: vulnerabilidad y riesgo de exclusión social. In: Torres, C. (ed.) España 2015. Situación Social. Centro de Investigaciones Sociológicas, Madrid (2015)

Baert, S., Bart, C., Verhaest, D.: Overeducation at the start of the career: stepping stone or trap? Labour Econ. 25, 123-140 (2013)

Bande, R., Karanassou, M.: Spanish regional unemployment revisited: the role of capital accumulation. Reg. Stud. 48(11), 1863-1883 (2014)

Banyuls, J., Miguélez, F., Recio, A., Cano, E., Lorente, R.: The transformation of the employment system in Spain: towards a mediterranean neoliberalism. In: Bosch, G., Lehndorff, S., Rubery, J. (eds.) European employment models in flux. A comparison of institutional change in Nine European Countries, pp. 247-269. Palgrave-Macmillan, New York (2009)

Barbieri, P., Scherer, S.: Labour market flexibilization and its consequences in Italy. Eur. Sociol. Rev. 25(6), 677-692 (2009)

Bell, D.N., Blanchflower, D.G.: Youth unemployment in Europe and the United States. Nordic. Econ. Policy Rev. 1, 11-38 (2011)

Belvis, F.X., Benach, J.: Educació i estabilitat laboral a Catalunya. Mobilitat entre ocupació estable, inestable i no ocupació, 2002-2012. Fundació Jaume Bofill, Barcelona. http://www.fbofill.cat/publicacions/educacioi-estabilitat-laboral-catalunya-0 (2014)

Bentolila, S., Dolado, J.J., Jimeno, J.F.: Two-tier employment protection reforms: the Spanish experience, CESifo DICE Report 4/2008. http:// www.cesifo.de (2008)

Bentolila, S., Cahuc, P., Dolado, J.J., Le Barbanchon, T.: Two-tier labour markets in the Great Recession: France versus Spain. Econ. J. 122, F155-F187 (2012)

Bernardi, F., Garrido, L.: Is there a new service proletariat? Post-industrial employment growth and social inequalities in Spain. Eur. Sociol. Rev. 24(3), 299-313 (2008)

Berton, F., Devicienti, F., Pacelli, L.: Are temporary jobs a port of entry into permanent employment? Evidence from matched employeremployee. Int. J. Manpower 32(8), 879-899 (2011)

Bruno, G.S.F., Caroleo, F.E., Dessy, O.: Stepping stones versus dead end jobs: exits from temporary contracts in Italy after the 2003 Reform (IZA discussion Paper No. 6746). http://hdl.handle.net/ (2012)

Cachón, L.: En la 'España inmigrante': entre la fragilidad de los inmigrantes y las políticas de integración. Papeles CEIC 1, 1-35 (2009)

Caparrós, A., Navarro, M.L.: Temporalidad, segmentación laboral y actividad productiva: ¿existen diferencias regionales? Estadística Española 50(168), 205-245 (2008)

Casal, J., García, M., Merino, R., Quesada, M.: Changes in forms of transition in contexts of informational capitalism. Papers. Revista de Sociologia $\mathbf{7 9}$ 195-223 (2006)

Castelló, L., Bolíbar, M.. Barranco, O., Verd, J.M.: Treball. Condicions en el mercat de treballi trajectòries laborals de la joventut catalana. In: Serracant, 
P. (ed.) Enquesta a la joventut de Catalunya 2012, vol. 1, pp. 117-218. Barcelona, Generalitat de Catalunya (2013)

Choudhry, M.T., Marelli, E., Signorelli, M.: Youth unemployment and the impact of financial crisis. Int. J. Manpower 33(1), 76-95 (2012)

De la Rica, S., Anghel, B.: Los parados de larga duración en España en la crisis actual. Documento de trabajo 185/2014. Fundación Alternativas, Madrid (2014)

Debels, A.: Transitions out of temporary jobs: consequences for employment and poverty across Europe. In: Muffels, R.J.A. (ed.) Flexibility and employment security in Europe, pp. 51-77. Labour markets in Transition, Edward Elgar, Cheltenham (2008)

Dietrich, H., Möller, J.: Youth unemployment in Europe: business cycle and institutional effects. Int. Econ. Econ. Policy 13(1), 5-25 (2016)

Doeringer, P., Piore, M.: Internal labor markets and manpower analysis. Heath and $C_{0}$, Lexington (1971)

Edwards, R.C.: The social relations of production in the firm and labour market structure. Polit. Soc. 5, 83-108 (1975)

Eichhorst, W., Marx, P., Wehner, C.: Labor market reforms in Europe: towards more flexicure labor markets? J. Labour Market Res. 51, 3 (2017)

Erikson, R:: Social class of men, women and families. Sociology 18(4), 500-514 (1984)

Freeman, R.B., Wise, D.A. (eds.): The youth labor market problem: its nature, causes and consequences. University of Chicago Press/NBER, Chicago (1982)

García-Pérez, J.I., Muñoz-Bullón, F.: Transitions into permanent employment in Spain: an empirical analysis for young workers. Br. J. Ind. Relat. 49(1), 103-143 (2011)

Hair Jr., J.F., Black, W.C., Babin, B.J., Anderson, R., Tatham, R.E.: Multivariate data analysis, 7th edn. Prentice Hall, New Jersey (2009)

Häusermann, S., Schwander, H.: Varieties of dualization? Labor market segmentation and insider-outsider divides across regimes. In: Emmenegger, P., Häusermann, S., Palier, B., Seeleib-Kaiser, M. (eds.) The age of dualization. The changing face of inequality in deindustrializing societies, pp. 27-51. Oxford University Press, Oxford (2012)

Hernanz, V.: El trabajo temporal y la segmentación: un estudio de las transiciones laborales. Consejo Económico y Social, Madrid (2003)

ILO: Spain growth with jobs. International Labour Office, Geneva (2014)

ILO: World employment and social outlook 2016: trends for youth. International Labour Office, Geneva (2016)

Kaliski, S.F.: Why must unmeployment remain so high? Can. Public Pol. 10(2), 127-141 (1984)

Korupp, S.E., Ganzeboom, H.B.G., Van Der Lippe, T.: Do mothers matter? A comparison of models of the influence of mothers and fathers educational and occupational status on children's educational attainment. Qual. Quant. 36, 17-42 (2002)

Lefresne, F.: Les jeunes et l'emploi. La Découverte, Paris (2003)

López-Andreu, M., Verd, J.M.: Employment instability and economic crisis in Spain: what are the elements that make a difference in the trajectories of younger adults? Eur. Soc. 18(4), 315-335 (2016)

López-Bazo, E., Montellón, E.:The regional distribution of unemployment: what do micro-data tell us? Pap. Reg. Sci. 92(2), 383-405 (2013)

Meroni, C.E., Vera-Toscano, E.: The persistence of overeducation among recent graduates. Labour Econ. 48, 120-143 (2017)

Mertens, A., Gash, V., McGinnity, F.: The cost of flexibility at the margin. Comparing the wage penalty for fixed-term contracts in Germany and Spain using Quantile Regression. Labour 21(4/5), 637-666 (2007)

Muñoz-de-Bustillo, R., Esteve, F.:The neverending story. Labour market deregulation and the performance of the Spanish labour market. In: Piasna, A., Myant, M. (eds.) Myths of employment deregulation: how it neither creates jobs nor reduces labour market segmentation, pp. 61-80. ETUI, Brussels (2017)

O'Higgins, N.: This Time It's Different? Youth labour markets during 'The Great Recession' (IZA discussion paper, No. 6434). Institute for the Study of Labor, Bonn (2012)

O'Reilly, J., Eichhorst, W., Gábos, A., Hadjivassiliou, K., Lain, D., Leschke, J., McGuinness, S., Kureková, L.M., Nazio, T., Ortlieb, R., Russell, H., Villa, P.: Five characteristics of youth unemployment in Europe: flexibility, education, migration, family legacies, and EU policy. SAGE Open 5(1), 1-19 (2015)

Osterman, P.: Getting started: the youth labor market. MIT Press, Camdridge (1980)
Pastore, F:: The youth experience gap. Explaining national differences in the school-to-work transition. Springer, Heidelberg (2015)

Pastore, F.: Why so slow? The school-to-work transition in Italy (IZA discussion paper, No. 10767). Institute for the Study of Labor, Bonn (2017)

Pastore, F., Giuliani, L.: The determinants of youth unemployment. A panel data analysis (CRISEI, discussion paper, No.2). University of Naples Parthenope, Naples (2015)

Prieto, C., Arnal, M., Caprile, M., Potrony, J.: La calidad del empleo en España: una aproximación teórica y empírica. Ministerio de Trabajo y Seguridad Social, Madrid (2009)

Prieto, C., Pérez de Guzmán, S.: La precarización del empleo en el marco de la norma flexible-empresarial de empleo. In:Torres, C. (ed.) España 2015. Situación social. Centro de Investigaciones Sociológicas, Madrid (2015)

Quintini, G., Martin, J., Martin, S.: The changing nature of the school-to-work transition process in OECD countries (IZA discussion paper, No. 2582). Institute for the Study of Labor, Bonn (2007)

Rocha, F:: La crisis económica y sus efectos sobre el empleo en España". Gaceta Sindical 19, 67-89 (2012a)

Rocha, F.: Youth unemployment in Spain. Situation and policy recommendations. Friedrich-Ebert-Stiftung, Berlin (2012b)

Ryan, P.: The school-to-work transition. A cross-national perspective. J. Econ. Lit. 39(1), 1-34 (2001)

Sala, H., Trivín, P.: Labour market dynamics in Spanish regions: evaluations asymmetries in troublesome times. SERIES 5, 197-221 (2014)

Salido, O.: La movilidad ocupacional de las mujeres en España. Por una sociología de la movilidad femenina. Centro de Investitgaciones Sociológicas, Madrid (2001)

Scherer, S.: Stepping-stones or traps? The consequences of labour market entry positions on future careers in West Germany, Great Britain and Italy. Work Employ Soc. 18(2), 369-394 (2004)

Serracant, P.: Changing youth? Continuities and ruptures in transitions into adulthood among Catalan young people. J. Youth Stud. 15(2), 161-176 (2012)

Tomlinson, M., Walker, R.: Labor market disadvantage and the experience of recurrent poverty. In: Emmenegger, P., Häusermann, S., Palier, B., SeeleibKaiser, M. (eds.) The age of dualization. The changing face of inequality in deindustrializing societies, pp. 52-70. Oxford University Press, Oxford (2012)

Verd, J.M., López-Andreu, M.: La inestabilidad del empleo en las trayectorias laborales Un análisis cuantitativo. Rev. Esp. Investig. Soc. 138, 135-148 (2012)

Verick, S.: The impact of the global financial crisis on labour markets in OECD countries: why youth and other vulnerable groups have been hit hard. In: Islam, I., Verick, S. (eds.) From the great recession to labour market recovery, pp. 119-145. Palgrave Macmillan, London (2011)

Ward, J.H.: Hierarchical grouping to optimize an objective function. J. Am. Stat. Assoc. 58, 236-244 (1963)

\section{Submit your manuscript to a SpringerOpen ${ }^{\circ}$ journal and benefit from:}

- Convenient online submission

- Rigorous peer review

- Open access: articles freely available online

- High visibility within the field

- Retaining the copyright to your article

Submit your next manuscript at $\boldsymbol{\nabla}$ springeropen.com 